Hak Cipta Dilindungi Undang-Undang

1. Dilarang mengutip sebagian atau seluruh karya tulis ini tanpa mencantumkan dan menyebutkan sumber:

a. Pengutipan hanya untuk kepentingan pendidikan, penelitian, penulisan karya ilmiah, penyusunan laporan, penulisan kritik atau tinjauan suatu masalah.

b. Pengutipan tidak merugikan kepentingan yang wajar Unand.

2. Dilarang mengumumkan dan memperbanyak sebagian atau seluruh karya fulis ini dalam bentuk apapun tanpa izin Unand.

\title{
IDENTIFIKASI MODEL ANTRIAN PADA ANTRIAN BUS KAMPUS UNIVERSITAS ANDALAS PADANG
}

\section{SKRIPSI}

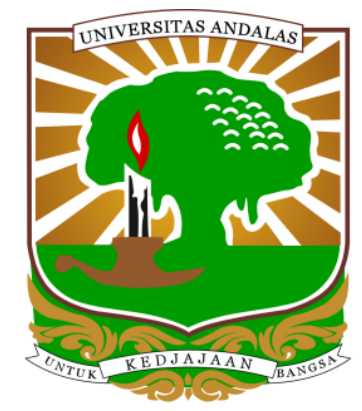

ZUL AHMAD ERSYAD

06934016

JURUSAN MATEMATIKA

FAKULTAS MATEMATIKA DAN ILMU PENGETAHUAN ALAM

UNIVERSITAS ANDALAS

PADANG 2012 


\section{KATA PENGANTAR}

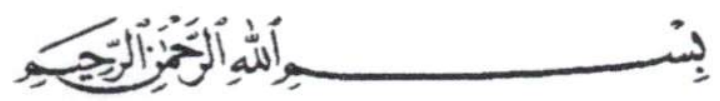

Syukur Alhamdulillah penulis aturkan kehadiran Allah SWT, yang telah melimpahkan rahmat dan hidayah-NYA, sehingga penulis dapat menyelesaikan skripsi yang berjudul " IDENTIFIKASI MODEL ANTRIAN PADA ANTRIAN BUS KAMPUS UNIVERSITAS ANDALAS PADANG ". Salawat dan salam kepada Rasulullah saw yang telah mengantarkan manusia dari abad kegelapan kepada abad yang terang dan berilmu pengetahuan. Penulisan skripsi ini merupakan salah satu syarat untuk menyelesaikan studi di Jurusan Matematika Fakultas Matematika dan Ilmu Pengetahuan Alam (FMIPA) Universitas Andalas Padang.

Penulis mengucapkan terima kasih yang sebesar-besarnya kepada :

1. Bapak Dr. Dodi Devianto, M.Sc sebagai pembimbing I yang telah banyak memberikan bimbingan, pengarahan dan saran kepada penulis sampai selesainya penyusunan tugas akhir ini.

2. Bapak Dr. Ahmad Iqbal Baqi, sebagai pembimbing II yang telah banyak memberikan bimbingan, pengarahan, saran dan waktu serta tenaga kepada penulis sampai selesainya penyusunan tugas akhir ini.

3. Ibu Izzati Rahmi HG M.Si, Bapak Narwen M.Si, dan Bapak Zulakmal, M.Si sebagai penguji yang telah banyak meluangkan waktu, membaca naskah skripsi, mengarahkan dan memberi koreksi atas penyempurnaan penulisan skripsi ini. 
4. Bapak Zulakmal, M.Si sebagai Penasehat Akademik yang telah membantu penulis merancang penyelesaian studi hingga selesai.

5. Ibu Dr. Lyra Yulianti sebagai koordinator pendidikan Jurusan Matematika Universitas Andalas.

6. Bapak Dr. Syafrizal Sy sebagai Ketua Jurusan Matematika Fakultas Matematika dan Ilmu Pengetahuan Alam Universitas Andalas Padang.

7. Seluruh Bapak/Ibu dosen dijurusan matematika yang telah memberikan bekal ilmu kepada penulis selama menjalani studi.

8. Seluruh Bapak /Ibu karyawan/karyawati Jurusan matematika FMIPA Unand yang telah mempelancar proses belajar selama penulis menjalani studi.

9. Sahabat-sahabatku mahasiswa Matematika angkatan 2006 FMIPA Unand, Arif, Heru, Ijon, Nia, Rido, Uci, Zaky, Iput, Mega dan semua yang tidak dapat disebutkan satu persatu, yang telah memberi semangat dan kebersamaan.

10. Sahabat-sahabat seperjuangan FMIPA PRODUCTION, Uda-uda, Uni-uni , Adek-adek terimakasih atas ilmu dan kebersamaannya.

11. Sahabat Youdhi \& Rolli yang telah banyak memberikan do'a, semangat, motivasi dan dorongan dalam penulisan skripsi ini.

12. Terakhir, terima kasih buat ucuk atas semua semangat dan do'anya semoga selalu jadi yang terbaik dan yang pasti semangat biar cepat selesai juga skripsinya. 
Terima kasih kepada yang mulia Ayahanda Syarifuddin B.A dan Ibunda tercinta Erna Dianit di kota Painan, Karena kasih sayang, do'a, dorongan dan semangat beliau, penulis dapat menyelesaikan tugas akhir ini tepat pada waktunya. Untuk Kakakku Syafrita Erna Dewi, adikku Sartika Sri Wahyuni dan Apri Yeli Zul Fadli Yanti, terima kasih untuk motivasi dan segala hal yang telah kita lalui bersama.

Penulis menyadari bahwa skripsi ini masih terdapat kekurangan. Untuk itu penulis sangat mengharapkan kritik dan saran atas kekurangan tersebut. Akhir kata semoga skripsi ini bermanfaat bagi kita semua. Amin

Padang, Agustus 2012 Penulis

Zul Ahmad Ersyad 


\begin{abstract}
ABSTRAK
Model antrian data kedatangan bus dan data keberangkatan bus yang diperoleh adalah model (M/G/1) : (FIFO/ / ). Tingkat kedatangan dan tingkat keberangkatan berdistribusi Poisson. Waktu antar kedatangan dan waktu antar bersifat umum. Disiplin antrian yang digunakan adalah bus yang pertama datang adalah bus yang pertama dilayani.
\end{abstract}

Kata kunci : $(\mathrm{M} / \mathrm{G} / 1):(\mathrm{FIFO} / \sim / \sim)$ 


\section{DAFTAR ISI}

KATA PENGANTAR ..................................................................... i

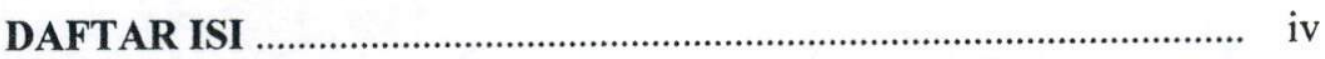

DAFTAR TABEL …...................................................................... vi

DAFTAR GAMBAR ...................................................................... viii

BAB I PENDAHULUAN _.....................................................

1.1 Latar Belakang ............................................................... 1

1.2 Perumusan Masalah ....................................................... 3

1.3 Pembatasan Masalah .......................................................... 3

1.4 Tujuan Penelitian ........................................................... 3

1.5 Manfaat Penelitian ......................................................... 4

BAB II LANDASAN TEORI …................................................ 5

2.1 Pengertian Teori Antrian .................................................. 5

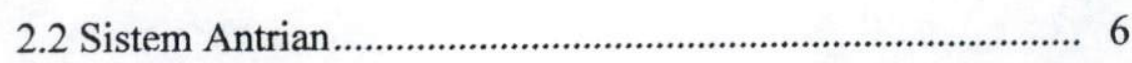

2.3 Disiplin Antrian............................................................... 6

2.4 Elemen - Elemen Dasar Teori Antrian ................................ 7

2.5 Model Model Antrian.......................................................... 9 
2.6 Teminologi dan Notasi

2.7 Pola keberangkatan dan Lama waktu antar keberangkatan ... 14

BAB III METODE PENELITIAN .17

3.1 Lokasi dan Waktu Penelitian 17

3.2 Pengumpulan Data 17

3.3 Alur Pengolahan data 18

BAB IV PEMBAHASAN

4.1 Gambaran umum antrian pada Terminal Bus Kampus Universitas Andalas Padang

4.2 Pengumpulan Data

4.3 Pengolahan data.

BAB V PENUTUP

5.1Kesimpulan

5.2 Saran 35

DAFTAR PUSTAKA 


\section{BAB I}

\section{PENDAHULUAN}

\subsection{Latar Belakang Masalah}

Manusia sebagai makhluk sosial, tidak akan terlepas dari peran serta orang lain dalam kehidupannya. Pada kondisi tertentu manusia pasti memerlukan jasa orang lain dalam memenuhi kebutuhan hidup, dan terkadang untuk mendapatkannya seseorang harus menunggu terlebih dahulu. Hal tersebut sangat mungkin terjadi, karena banyak orang yang memerlukan jasa yang sama dalam waktu yang bersamaan pula. Kondisi tersebut sering terlihat dalam kehidupan sehari-hari, seperti menunggu untuk mendapatkan tiket pesawat, menunggu untuk mendapatkan karcis sebuah pertandingan sepak bola ataupun menunggu untuk mendapatkan pelayanan di bank.

Proses antrian merupakan suatu proses yang berhubungan dengan kedatangan pelanggan pada suatu fasilitas pelayanan, menunggu dalam baris antrian jika belum dapat dilayani, dilayani dan akhirnya meninggalkan fasilitas tersebut sesudah dilayani. Proses ini lazim dijumpai di tempat-tempat pelayanan umum, salah satu contohnya adalah antrian bus di halte. Untuk menganalisis permasalahan antrian bus dihalte ini digunakan aplikasi teori antrian pada sistem diterminal tersebut. Langkah yang perlu dilakukan adalah dengan mengadakan suatu penelitian di mana antrian tersebut terjadi. 
Antrian juga terjadi di terminal bus kampus Universitas Andalas, Pasar Baru kota Padang, Sumatera Barat. Terminal bus kampus Pasar Baru yang menjadi obyek penelitian, mempunyai satu jalur kedatangan dan keberangkatan yaitu Pasar Baru-Kampus Universitas Andalas yang berjarak sekitar $3 \mathrm{KM}$. Ini menunjukkan bahwa satu - satunya loket pelayanan adalah terminal Pasar Baru. Bus yang menjadi obyek penelitian adalah unit bus kampus milik Universitas Andalas. Hal ini karena di kampus Universitas Andalas, bus yang diizinkan beroperasi hanya bus kampus milik Universitas Andalas.

Dari uraian di atas, dengan menyadari arti pentingnya mengoptimalkan saluran keberangkatan yang lebih baik pada teminal bus Pasar Baru, maka perlu adanya perbaikan kinerja dari proses pelayanan yang mempunyai sifat ketidakpastian tersebut. Dengan demikian dapat optimal dalam melayani mahasiswa menuju ke kampus, sehingga tidak ada bus yang terlalu penuh berangkat atau bus setengah terisi mahasiswa yang berangkat menuju kampus Universitas Andalas. 


\subsection{Perumusan Masalalı}

Masalah yang akan dibahas adalah bagaimana model yang paling tepat untuk antrian bus kampus Universitas Andalas Padang.

\subsection{Pembatasan Masalah}

Untuk menentukan model antrian tunggal pada Terminal bus kampus Universitas Andalas Padang, maka permasalahan yang dibahas dibatasi untuk halhal berikut ini

1. Pembatasan masalah dilakukan hanya yang menyangkut proses antrian bus kampus yang meninggalkan halte pasar baru Padang menuju kampus Universitas Andalas.

2. Lapaoran hasil penelitian ini membatasi masalah dalam mengidentifikasi model antrian yang cocok berdasarkan data-data yang ditemui di lapangan.

\subsection{Tujuan Penelitian}

Adapun tujuan penelitian yang hendak dicapai dari penulisan ini adalah untuk

1. Memberikan model antrian tunggal pada terminal bus kampus Universitas Andalas Padang.

2. Mengoptimalkan saluran pelayanan tunggal pada terminal Pasar Baru, sehingga bus tidak lama untuk mengantri di terminal.

\subsection{Manfaat Penelitian}

Dari tulisan ini, diharapkan dapat bermanfaat sebagai berikut 
1. Bagi unit pengelola bus kampus Universitas Andalas Padang, diharapkan dapat menjadi informasi tambahan dalam menentukan tingkat laju keberangkatan antrian dan model antrian yang akan diterapkan.

2. Bagi peneliti selanjutnya, diharapkan dapat menjadi masukan yang berguna sebagai landasan untuk penelitian selanjutnya. 


\section{BAB II}

\section{LANDASAN TEORI}

\subsection{Pengertian Teori Antrian}

Teori Antrian (queueing teory) merupakan studi matematika dari antrian atau kejadian garis tungggu (waiting lines), yakni suatu garis tunggu dari pelangggan yang memerlukan layanan dari sistem pelayanan yang ada. Hal ini sering kita jumpai dalam kegiatan sehari-hari. Diantaranya menunggu di depan loket-loket pembayaran rekening, menunggu tiket kereta api, menunggu di pintu jalan tol. Dimana langganannya adaiah konsumen yang datang, sedangkan loket merupakan tempat pelayanan. Rata-rata lamanya waktu untuk menunggu sangat bergantung pada rata-rata tingkat kecepatan layanan. Menunggu dapat terjadi karenan kebutuhan akan layanan yang melebihi kapasitas pelayanan yang ada, akan mengakibatkan konsumen yang datang tidak segera terlayani. [5]

Kejadian menunggu adalah hasil langsung dari keacakan dalam operasi sarana pelayanan secara umum, kedatangan pelanggan dan waktu pelayanan tidak diketahui sebelumnya, karena jika bisa diketahui, pengoperasian sarana tersebut dapat dijadwalkan sedemikian rupa sehingga akan sepenuhnya menghilangkan keharusan untuk menunggu. Tujuan mempelajari pengoperasian sebuah sarana pelayanan dalam kondisi acak adalah untuk memperoleh beberapa karakteristik yang mengukur kinerja sistem yang sedang dipelajari.

Pada model antrian, hubungan antara bus dan penumpang adalah berkaitan dengan periode waktu yang diperoleh bus untuk menyelesaikan sebuah antrian. 
Dalam kaitannnya dengan antrian keberangkatan bus seharusnya dapat dibagi menjadi distribusi keberangkat dan distribusi waktu antar keberangkatan.

\subsection{Sistem Antrian}

Bus yang tiba dapat bersifat tetap atau tidak tetap untuk memperoleh antrian. Apabila bus yang tiba dapat masuk langsung kedalam sitem antian maka bus tersebut akan segera dilayani, sebaliknya jika harus menunggu maka mereka harus membentuk antrian hingga tiba waktu keberangkatan. [3]

\subsection{Disiplin Antrian}

Disiplin antrian adalah konsep yang membahas mengenai kebijakan dimana para pelanggan dipilih dari antrian untuk dilayani. Menurut Thomas J Kakiay berdasarkan urutan kedatangan pelanggan. Ada 4 bentuk disiplin pelayanan yang biasa digunakan dalam praktek yaitu

1. First Come First Served (FCFS) atau First In First out (FIFO) yaitu pelanggan yang datang lebih dulu akan dilayani lebih dulu. Misalnya : sistem antrian pada bank, SPBU, dan lain - lain.

2. Last Come First Served (LCFS) atau Last In First Out (LIFO) yaitu sistem antrian pelanggan yang datang terakhir akan dilayani lebih dulu. Misalnya : sistem antrian dalam elevator lift untuk lantai yang sama.

3. Service In Random Order (SIRO) yaitu panggilan didasarkan pada peluang secara acak. Disiplin antrian ini biasanya timbul dalam keadaan praktis. 
4. Priority Service (PS) yaitu pelayanan diberikan kepada mereka yang mempunyai prioritas lebih tinggi dibandingkan dengan mereka yang mempunyai prioritas lebih rendah. Disiplin antrian ini dapat disebabkan oleh beberapa hal, misalnya seseorang yang karena kedudukan atau jabatannya lebih tinggi menyebabkan dia dipanggil terlebih dahulu atau diberi prioritas lebih tinggi, atau seseorang yang keadaan penyakitnya lebih berat dibanding dengan orang lain dalam suatu tempat praktek dokter.

\subsection{Elemen - Elemen Dasar Teori Antrian}

Adapun elemen - elemen dasar dalam teori antrian adalah

\subsubsection{Sumber Masukan (Input)}

Sumber adalah kumpulan informasi tentang arus kedatangan bus dan arus keberangkatan dalam satuan waktu tertentu. Untuk menentukan arus kedatangan rata-rata dalam satuan waktu tertentu, kita memerlukan suatu data kedatangan dalam selang waktu tertentu. Pada arus keberangkatan rata-rata, kita memerlukan suatu data keberangkatan dalam selang waktu yang sama.

\subsubsection{Pola kedatangan}

Kedatangan bus ke dalam sistem mengikuti proses antrian, yaitu banyaknya bus yang datang sampai pada waktu tertentu mempunyai distribusi kedatangan tertentu. Hal ini karena kedatangan bus secara acak pada kecepatan kedatangan rata-rata tertentu. 


\subsubsection{Mekanisme Pelayanan}

Mekanisme pelayanan adalah jumlah susunan stasiun, yang terdiri dari satu atau lebih stasiun pelayanan disusun seri atau pararel, gabungan. Suatu model dikatakan pelayanan tunggal apabila sistem hanya mempunyai satu stasiun pelayanan dan model dikatakan model pelayanan ganda bila stasiun pelayanan lebih dari satu.

\subsubsection{Proses Poisson}

Proses Poisson menggambarkan munculnya suatu kejadian pada titik-titik waktu secara acak, dimana dalam proses pencacahan banyaknya jumlah kedatangan selama suatu selang waktu tertentu yang berdistribusi poisson. Sebagai contoh adalah masuknya pesan SMS (Short Message Service) pada handphone, panggilan telepon, computer jobs untuk dikompilasi dan dieksekusi oleh suatu komputer, jaringan yang membawa paket data untuk menyampaikan informasi, mengukur lalu lintas yang melewati suatu jaringan, dimana setiap saat ada data yang lewat.

\subsubsection{Barisan Antri}

Suatu antrian selalu ditandai dari banyaknya jumlah bus yang ada di dalam sistem untuk mendapatkan pelayanan. Antrian disebut terbatas apabila jumlah bus yang dibolehkan masuk ke dalam sisten dibatasi sampai jumlah tertentu, bila pembatasan yang demikian tidak diadakan, maka antrian dikatakan tidak terbatas. 


\subsubsection{Keluar (Exit)}

Sesudah sebuah bus masuk dan menunggu, bus keluar (exit) dari halte. Sesudah keluar, bus tersebut berangkat lagi menuju kampus. Bus tersebut masuk antrian dan bergabung kembali dengan populasi asal. Dengan demikian bus tersebut mempunyai probabilitas yang sama untuk memasuki sistem antrian kembali.

\subsubsection{Waktu Pelayanan}

Waktu yang diperlukan untuk bus, sejak mulai beroperasi hingga selesai disebut waktu pelayanan. Waktu pelayanan ini juga mempunyai suatu distribusi probabilitas, yakni ditentukan berdasarkan data - data yang diperoleh dilapangan.

\subsection{Model - Model Antrian}

Adapun model- model antrian adalah

\subsubsection{Single Channel - Single Phase}

Single Chanel berarti bahwa hanya ada satu jalur untuk memasuki sistem pelayanan atau ada satu pelayanan. Single Phase menunjukan bahwa hanya ada satu stasiun pelayanan sehingga yang telah menerima pelayanan dapat langsung keluar dari sistem antrian. Misalnya adalah pada pembelian tiket bus yang dilayani oleh satu loket, pelayanan konsumen pada kasir di sebuah swalayan ramai di pusat kota. 


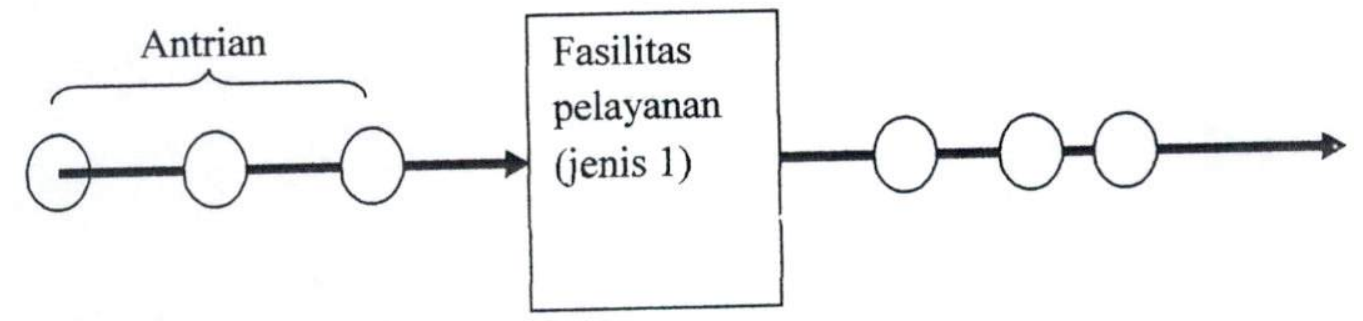

Gambar 2.5.1 Single Channel-Single Phase

\subsubsection{Single Channel - Multi Phase}

Multi phase berarti ada dua atau lebih pelayanan yang dilaksanakan secara berurutan dalam phase-phase. Misalnya pada proses pencucian mobil, di mana pelayanan 1 adalah pencucian, sedangkan pelayanan 2 adalah pengeringan.

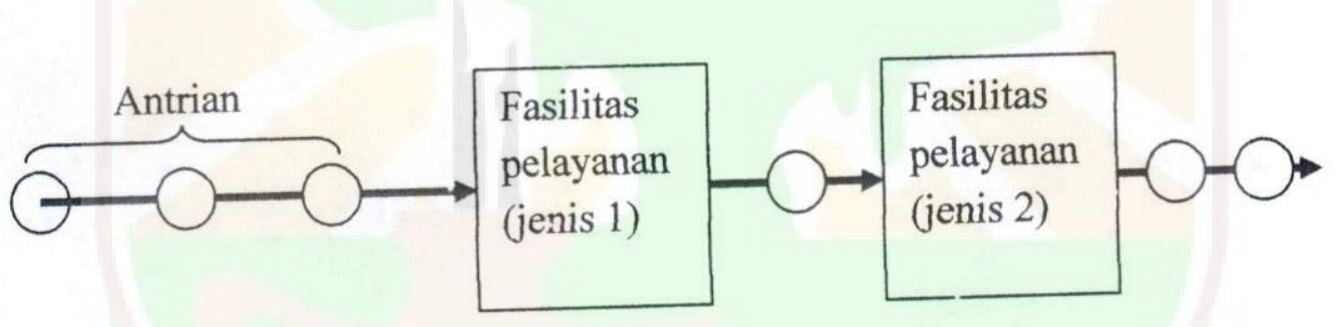

Gambar 2.5.2 Single Channel Multi Phase

\subsubsection{Multichannel - Single Phase}

Sistem multi chanel- single phase terjadi jika ada dua atau lebih fasilitas pelayanan dialiri oleh suatu antrian tunggal. Sebagai contoh adalah pada pembelian tiket yang dilayani oleh lebih dari satu loket, pelayanan nasabah di bank, pelayanan antrian pada pembelian tiket sepak bola dan bioskop. 


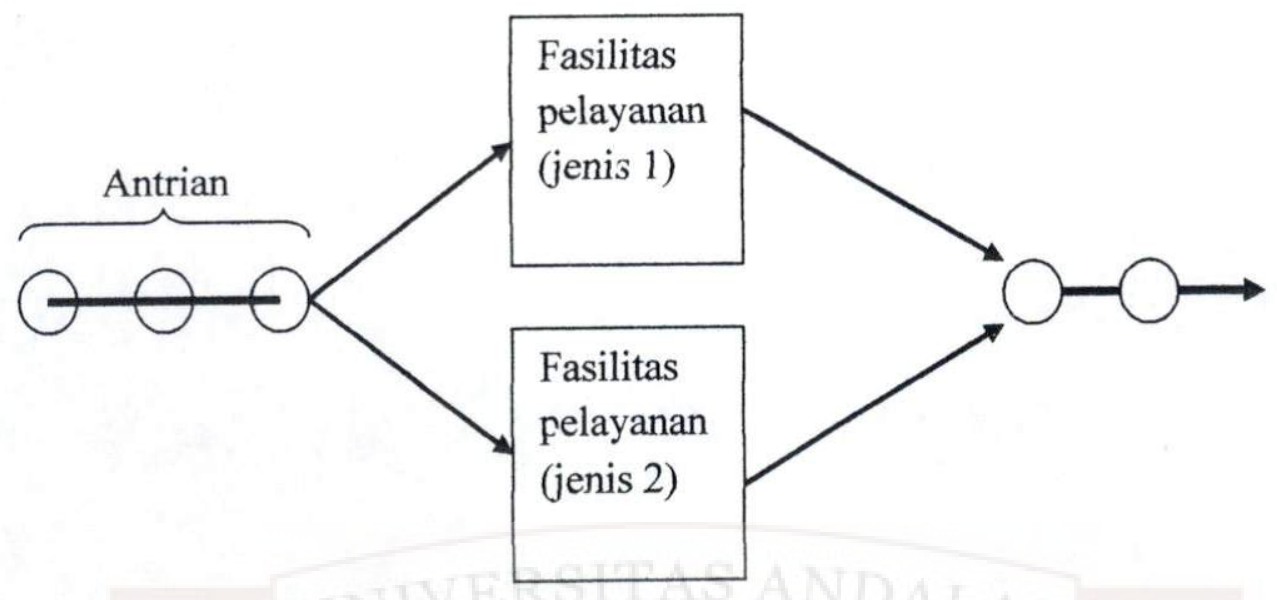

Gambar 2.5.3 Multi Channel Single Phase

\subsubsection{Multichannel - Multi Phase}

Sistem ini terjadi jika ada dua atau lebih fasilitas pelayanan dengan pelayanan pada lebih dari satu phase. Sebagai contoh adalah pada pelayanan kepada pasien di rumah sakit dari pendaftaran, diagnosa, tindakan medis sampai pembayaran. Setiap sistem-sistem ini mempunyai beberapa fasilitas pelayanan pada setiap tahap, sehingga lebih dari satu individu dapat dilayani pada suatu waktu.

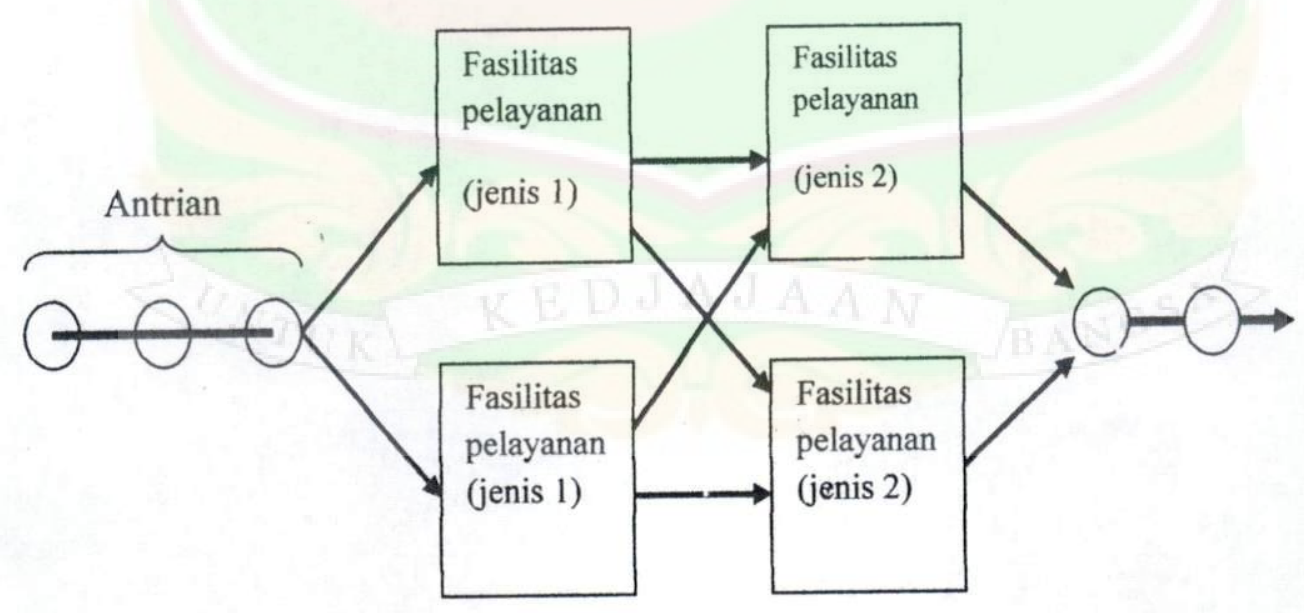

Gambar 2.5.4 Multi Channel Multi Phase 


\subsection{Terminologi dan Notasi}

Terminologi dan notasi yang biasa digunakan dalam sistem antrian adalah sebagai berikut

1. Keadaan sistem adalah jumlah atau banyaknya aktifitas pelayanan yang melayani satuan bus dalam sistem.

2. Panjang antrian adalah banyaknya satuan yang berada dalam sistem dikurangi dengan jumlah satuan yang sedang beroperasi.

Notasi yang digunakan adalah sebagai berikut

$$
\begin{aligned}
& n=\text { jumlah objek dalam sistem antrian pada waktu } t \\
& c \quad=\text { jumlah stasiun } \\
& P_{n}(t)=\text { peluang bahwa ada objek yang masuk dalam antrian dalam } \\
& \text { waktu t } \\
& \lambda=\text { tingkat kedatangan objek } \\
& 1 / \lambda=\text { rata-rata kedatangan objek } \\
& \lambda \Delta t=\text { peluang bahwa ada satu satuan objek yang masuk dalam antrian } \\
& \text { selama waktu } t \\
& \mu \quad=\text { tingkat pelayanan } \\
& 1 / \mu=\text { rata-rata waktu pelayanan } \\
& \mu \Delta t=\text { peluang bahwa ada satu objek yang selesai dilayani selama waktu } \mathrm{t} \\
& \rho \quad=\quad \text { tingkat kesibukan sistem } \\
& c \mu \quad=\text { faktor untuk fasilitas satuan pelayanan } \\
& L \quad=\quad \text { ekspektasi panjang garis }
\end{aligned}
$$




$$
\begin{aligned}
& L q \quad=\text { ekspektasi panjang antrian } \\
& W \quad=\text { ekspektasi waktu menunggu dalam sistem } \\
& W q \quad=\text { ekspektasi obyek menunggu dalam antrian. }
\end{aligned}
$$

Untuk kemudahan dalam memahami karakteristik suatu sistem antrian digunakan notasi Kendall Lee yaitu format umum $(\mathrm{a} / \mathrm{b} / \mathrm{c}):(\mathrm{d} / \mathrm{e} / \mathrm{f})$. Notasi tersebut mempunyai arti sebagai berikut
a : bentuk distribusi keberangkatan, yaitu jumlah kedatangan setiap pertambahan waktu
$b \quad$ : bentuk distribusi antar keberangkatan, yaitu selang waktu antara satu-satuan bus yang berangkat
$c \quad: \quad$ jumlah saluran dalam sistem
d : disiplin pelayanan
e $\quad: \quad$ jumlah maksimum yang diperkenankan berada dalam sistem
f : besarnya populasi masukan

Simbol $a$ dan $b$ untuk keberangkatan dan waktu antar keberangkatan sering juga diganti penyimbolannya dengan kode-kode sebagai berikut

M : distribusi keberangkatan poisson atau distribusi waktu antar keberangkatan eksponensial

D : $\quad$ waktu pelayanan tetap

G : distribusi umum keberangkatan atau waktu pelayanan

Simbol $d$ untuk disiplin pelayanan sering juga diganti penyimbolannya dengan FIFO atau FCFS, LIFO atau LCFS, dan SIRO. 
Untuk huruf $c$, dipergunakan bilangan bulat positif yang digunakan untuk menunjukkan jumlah saluran keberangkatan. Untuk huruf $e$ dan $f$ digunakan kode $\mathrm{N}$ atau menyatakan jumlah terbatas atau tak berhingga satusatuan dalam sistem antrian dan populasi masukkan.

Misalnya pada penulisan model $(\mathrm{M} / \mathrm{M} / 1)$ : (FCFS/ / ). Pada model ini $\mathrm{M}$ pertama menyatakan keberangkatan berdistribusi poisson, $\mathrm{M}$ kedua menyatakan waktu antar keberangkatan berdistribusi eksponensial, jumlah satuan pelayanan satu. FCFS adalah pelayanan First Come First Serve adalah disiplin pelayanan dalam antrian. Jumlah keberangkatan bus yang keluar antrian tidak berhingg dalam sistem antrian dan ukuran (besarnya) populasi keberangkatan juga tidak berhingga.

\subsection{Pola keberangkatan dan Lama waktu antar keberangkatan}

\subsubsection{Pola Keberangkatan}

Distribusi Poisson digunakan untuk menggambarkan pola distribusi data. Data keberangkatan di asumsikan bahwa jumlah keberangkatan adalah acak dan keberangkatan bus adalah dalam interval waktu yang saling tidak mempengaruhi. Probablitas tepat terjadinya $x$ kedatangan dalam distribusi Poisson dapat diketahui dengan menggunakan rumus

$$
\mathrm{P}(x)=\frac{\lambda^{x} e^{-\lambda}}{x !}, \quad x=0,1,2, . .
$$

dimana

$P(x) \quad=$ Peluang bahwa ada $\mathrm{x}$ keberangkatan dalam sistem

$\lambda \quad=$ Tingkat keberangkatan rata - rata 
$e \quad=$ Bilangan eksponensial $(\mathrm{e}=2.71828)$
$x \quad=$ Variabel acak yang menyatakan keberangkatan per interval waktı

\subsubsection{Uji Kesesuaian Poisson}

Untuk menghitung nilai $\chi^{2}$ dari data pengamatan pada $x_{1}, x_{2}$ sampai $x_{n}$ terlebih dahulu diuji nilai ekspektasi kedatangan bus dengan menggunakan rumus distribusi Poisson. Untuk menentukan nilai $\chi^{2}$ maka digunakan rumus

$$
\chi^{2}=\frac{(f(x)-E(x))^{2}}{E(x)}
$$

Dengan $f(x)$ menyatakan frekuensi teramati dan $E(x)$ frekuensi harapan bagi sebaran ke- $i$. Kriteria keputusan dilakukan dengan terima rata-rata pelayanan berdistribusi Poisson apabila $\chi^{2}$ hitung $\leq \chi^{2}$ tabel, jika sebaliknya yaitu $\chi^{2}$ hitung $>\chi_{\text {tabel }}^{2}$ maka rata-rata pelayanan tidak dapat dikatakan berdistribusi Poisson.

\subsubsection{Lama waktu antar keberangkatan}

\subsubsection{Uji kesesuaian eksponensial}

Untuk menghitung nilai $\chi^{2}$ dari data pengamatan pada $x_{1}, x_{2}$ sampai $x_{n}$ terlebih dahulu ditentukan nilai ekspektasi waktu keberangkatan dengan menggunakan rumus distribusi eksponensial

Lama pelayanan yang dihitung sejak keberangkatan bus dalam sistem antrian sampai selesai pelayanan mengikuti distribusi eksponensial. Ini bisa dilakukan dengan membandingkan sampel waktu keberangkatan yang sebenarnya dengan waktu keberangkatan yang diharapkan berdasarkan rumus 
sebagai berikut

$$
f(x)=\mu e^{-\mu x},
$$

dimana

$\mu=$ rata rata tiap keberangkatan (unit keberangkatan per unit waktu)

$e=$ bilangan eksponensial $(e=2.71828)$

$x=$ waktu lama nya keberangkatan (unit keberangkatan per unit waktu)

. Untuk menentukan nilai $\chi^{2}$ maka digunakan rumus

$$
\chi^{2}=\frac{(f(x)-E(x))^{2}}{E(x)}
$$

Dengan $f(x)$ menyatakan frekuensi teramati dan $E(x)$ frekuensi harapan bagi sebaran ke-i. Kriteria keputusan dilakukan dengan terima ratarata waktu pelayanan berdistribusi eksponensial apabila $\chi^{2}$ hitung $\leq \chi^{2}$ tabel, jika sebaliknya yaitu $\chi^{2}$ hitung $>\chi^{2}$ tabel maka rata-rata pelayanan tidak dapat dikatakan berdistribusi eksponensial. 


\section{BAB III}

\section{METODE PENELITIAN}

\subsection{Lokasi dan Waktu Penelitian}

Adapun lokasi dan waktu penelitian yang dilakukan oleh penulis adalah

Lokasi : Halte Bus Kampus Universitas Andalas Pasar Baru Padang Jl.Pasar Baru Padang - Sumatera Barat

Waktu : Senin, Tanggal 06 Februari 2012. Penelitian ini di lakukan dari pukul $06.00-12.00$ WIB ini di karenakan pengoperasian bus dari jam 06.00 - 12.00 berjalan normal, penelitian ini dilakukan pada hari senin karena hari senin merupakan hari awal kegiatan kemahasiswaan berlangsung.

\subsection{Pengumpulan Data}

\section{- Metode Pengumpulan Data}

Pengumpulan data dilakukan dengan observasi lapangan sehinggga menggambarkan realitas masalah antrian yang sebenarnya. Adapun data yang diambil adalah data primer yaitu dengan menghitung jumlah antrian dan lama waktu antar keberangkatan bus kampus di halte Pasar Baru Padang yang sedang beroperasi pada halte tersebut. Pengumpulan data dilakukan dengan mempelajari dan menelaah buku-buku, jurnal dan tulisan yang berhubungan dengan penelitian ini. 
- Alat

Adapun alat yang digunakan dalam penelitian ini adalah Stopwach, yang digunakan untuk perhitungan lama waktu antar kedatangan.

\subsection{Alur Pengolahan data}

Data yang digunakan pada penelitian ini adalah data yang bersifat primer yaitu mengambil data dan melakukan penelitian langsung pada halte Pasar Baru Padang. Jenis penelitian ini merupakan penelitian dengan pendekatan kuantitatif yang terdiri atas perumusan masalah, menyusun model, mendapatkan data, mencari solusi, menguji solusi, menganalisis hasil dan mengimplementasikan hasil. 
Proses antrian yang digunakan pada bus kampus Universitas Andalas sebagai berikut
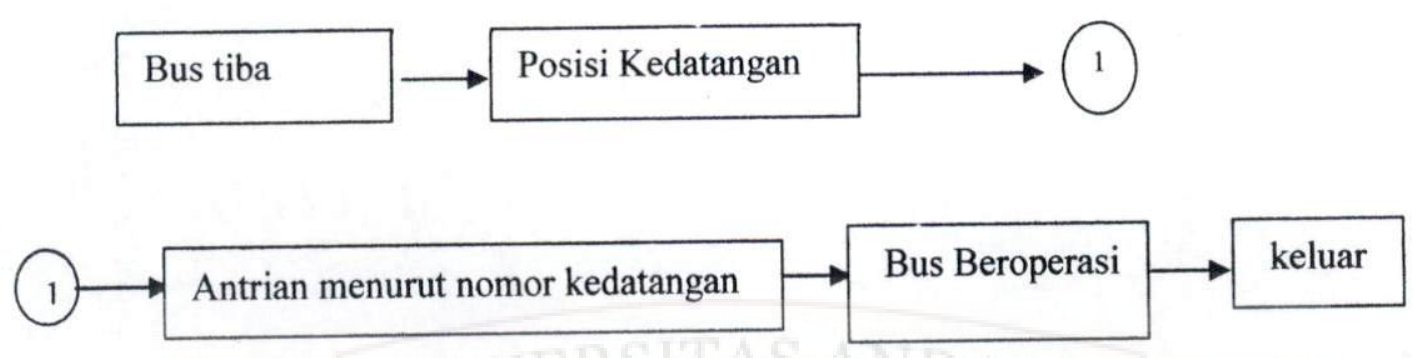

Gambar 4.2 Proses antrian bus

Bus yang diamati dalam sistem antrian adalah bus yang mengangkut setiap orang yang hendak menuju dan meninggalkan kampus Universitas Andalas Padang.

\subsection{Pengumpulan Data}

Data yang digunakan dalam penelitian ini adalah data yang diperoleh dari pengamatan langsung pada pengoperasian bus kampus Universitas Andalas di terminal Pasar Baru Padang. Pengamatan dilakukan pada tanggal 06 Februari 2012 selama 1 hari, yaitu mulai dari jam 06.00 WIB sampai dengan jam 12.00 WIB. Pencatatan lama waktu-waktu tersebut berdasarkan perhitungan dengan memakai stopwatch yaitu mulai dari bus datang, bus dilayani, sampai bus selesai dilayani.

Dalam sistem antrian kita membutuhkan informasi tentang arus kedatangan, waktu pelayanan dan arus keberangkatan dalam satu satuan waktu tertentu. Untuk mengetahui arus kedatangan rata-rata dalam satuan waktu tertentu kita memerlukan suatu data kedatangan dalam selang waktu tertentu. Begitu juga pada arus keberangkatan rata-rata, kita memerlukan suatu data keberangkatan 
dalam selang waktu yang sama. Pada penelitian ini, peneliti menetapkan satuan waktunya selama 15 menit selama 1 hari pengoperasian mulai dari jam 06.0012.00 WIB.

\subsubsection{Data Kedatangan}

Dari pengumpulan data di lapangan maka diperoleh jumlah kedatangan bus tiap 15 menit selama 360 menit, sebagai berikut

Tabel 4.1 Data kedatangan bus

\begin{tabular}{|c|c|c|c|}
\hline $\begin{array}{c}\text { Nomor } \\
\text { Observasi } \\
(i) \\
\end{array}$ & $\begin{array}{c}\text { Waktu } \\
\text { Observasi }\end{array}$ & $x_{i}$ & $\begin{array}{c}\text { Frekuensi } \\
\text { Kedatangan } \\
\left(f\left(x_{i}\right)\right)\end{array}$ \\
\hline 1 & $06.00-06.15$ & 0 & 0 \\
\hline 2 & $06.15-06.30$ & 1 & 0 \\
\hline 3 & $06.30-06.45$ & 2 & 1 \\
\hline 4 & $06.45-07.00$ & 3 & 2 \\
\hline 5 & $07.00-07.15$ & 4 & 4 \\
\hline 6 & $07.15-07.30$ & 5 & 9 \\
\hline 7 & $07.30-07.45$ & 6 & 15 \\
\hline 8 & $07.45-08.00$ & 7 & 20 \\
\hline 9 & $08.00-08.15$ & 8 & 20 \\
\hline 10 & $08.15-08.30$ & 9 & 19 \\
\hline 11 & $08.30-08.45$ & 10 & 13 \\
\hline 12 & $08.45-09.00$ & 11 & 10 \\
\hline 13 & $09.00-09.15$ & 12 & 9 \\
\hline 14 & $09.15-09.30$ & 13 & 7 \\
\hline 15 & $09.30-09.45$ & 14 & 7 \\
\hline 16 & $09.45-10.00$ & 15 & 3 \\
\hline 17 & $10.00-10.15$ & 16 & 3 \\
\hline 18 & $10.15-10.30$ & 17 & 2 \\
\hline 19 & $10.30-10.45$ & 18 & 2 \\
\hline 20 & $10.45-11.00$ & 19 & 1 \\
\hline 21 & $11.00-11.15$ & 20 & 1 \\
\hline 22 & $11.15-11.30$ & 21 & 1 \\
\hline 23 & $11.30-11.45$ & 22 & 0 \\
\hline 24 & $11.45-12.00$ & 23 & 0 \\
\hline
\end{tabular}


Banyak bus yang datang memasuki halte Pasar Baru selama 360 menit adalah sebanyak 149 unit, dengan $x_{i}$ adalah peubah acak yang menyatakan banyaknya bus yang masuk halte sedangkan $f\left(x_{i}\right)$ sebagai frekuensi kedatangan bus.

\subsubsection{Data Keberangkatan}

Dari pengumpulan data di lapangan maka diperoleh jumlah keberangkatan bus tiap 15 menit selama 360 menit, sebagai berikut

\section{Tabel 4.2. Data Keberangkatan Bus}

\begin{tabular}{|c|c|c|c|}
\hline $\begin{array}{c}\text { Nomor } \\
\text { Observasi } \\
(i)\end{array}$ & Waktu & $y_{i}$ & $\begin{array}{c}\text { Frekuensi } \\
\text { Keberangkatan } \\
\left(f\left(y_{i}\right)\right) \\
\end{array}$ \\
\hline 1 & $06.00-06.15$ & 0 & 0 \\
\hline 2 & $06.15-06.30$ & 1 & 0 \\
\hline 3 & $06.30-06.45$ & 2 & 0 \\
\hline 4 & $06.45-07.00$ & 3 & 2 \\
\hline 5 & $07.00-07.15$ & 4 & 4 \\
\hline 6 & $07.15-07.30$ & 5 & 9 \\
\hline 7 & $07.30-07.45$ & 6 & 15 \\
\hline 8 & $07.45-08.00$ & 7 & 18 \\
\hline 9 & $08.00-08.15$ & 8 & 16 \\
\hline 10 & $08.15-08.30$ & 9 & 18 \\
\hline 11 & $08.30-08.45$ & 10 & 11 \\
\hline 12 & $08.45-09.00$ & 11 & 10 \\
\hline 13 & $09.00-09.15$ & 12 & 8 \\
\hline 14 & $09.15-09.30$ & 13 & 7 \\
\hline 15 & $09.30-09.45$ & 14 & 7 \\
\hline 16 & $09.45-10.00$ & 15 & 3 \\
\hline 17 & $10.00-10.15$ & 16 & 3 \\
\hline 18 & $10.15-10.30$ & 17 & 2 \\
\hline 19 & $10.30-10.45$ & 18 & 2 \\
\hline 20 & $10.45-11.00$ & 19 & 1 \\
\hline 21 & $11.00-11.15$ & 20 & 1 \\
\hline 22 & $11.15-11.30$ & 21 & 1 \\
\hline 23 & $11.30-11.45$ & 22 & 0 \\
\hline 24 & $11.45-12.00$ & 23 & 0 \\
\hline
\end{tabular}


Banyaknya bus yang berangkat keluar dari halte bus Pasar Baru selama 360 menit adalah sebanyak 138 unit, dengan $y_{i}$ adalah peubah acak yang menyatakan banyaknya bus yang keluar meninggalkan halte sedangkan $f\left(y_{i}\right)$ sebagai frekuensi keberangkatan bus.

\subsection{Pengolahan Data}

\section{$\leftarrow$ 4.3.1 Pola Kedatangan Bus}

\section{Uji Kesesuaian Poisson}

Untuk menghitung nilai $\chi^{2}$ dari data pengamatan pada $x_{1}, x_{2}$ sampai $x_{n}$ terlebih dahulu ditentukan nilai harapan kedatangan bus dengan menggunakan rumus distribusi Poisson. Untuk menentukan nilai $\chi^{2}$ maka digunakan rumus

$$
\chi^{2}=\frac{(f(x)-E(x))^{2}}{E(x)}
$$

dengan $f(x)$ menyatakan frekuensi teramati data ke-i dan $E(x)$ frekuensi harapan untuk data ke- $i$. Kriteria keputusan dilakukan dengan terima rata-rata pelayanan berdistribusi Poisson apabila nilai $\chi^{2}$ hitung $\leq \chi^{2}$ tabel, jika sebaliknya yaitu $\chi^{2}$ hitung $\geq \chi^{2}$ tabel maka rata-rata pelayanan tidak dapat dikatakan berdistribusi poisson. 
Tabel 4.3. Uji Data Kedatangan Bus Dengan Distribusi Poisson

\begin{tabular}{|c|c|c|c|c|c|c|}
\hline $\begin{array}{c}\text { Lima belas } \\
\text { menit ke }\end{array}$ & $\boldsymbol{x}_{\boldsymbol{i}}$ & $\begin{array}{c}\text { Masuk } \\
\left(\boldsymbol{f}\left(\mathbf{x}_{\mathbf{i}}\right)\right)\end{array}$ & $\boldsymbol{x}_{\boldsymbol{i}} f\left(\boldsymbol{x}_{\boldsymbol{i}}\right)$ & $\boldsymbol{P}\left(\boldsymbol{x}_{\boldsymbol{i}}\right)$ & $\boldsymbol{E}\left(\boldsymbol{x}_{\boldsymbol{i}}\right)$ & $\frac{[\boldsymbol{f}(\boldsymbol{x} \boldsymbol{i})-\boldsymbol{E}(\boldsymbol{x} \boldsymbol{i})] \mathbf{2}}{\boldsymbol{E}(\boldsymbol{x} \boldsymbol{i})}$ \\
\hline $06.00-06.15$ & 0 & 0 & 0 & 0,000088 & 0,013234 & 0,01323 \\
\hline $06.15-06.30$ & 1 & 0 & 0 & 0,000828 & 0,123464 & 0,123464 \\
\hline $06.30-06.45$ & 2 & 1 & 2 & 0,003865 & 0,575892 & 0,312327 \\
\hline $06.45-07.00$ & 3 & 2 & 6 & 0,012018 & 1,790806 & 0,024437 \\
\hline $07.00-07.15$ & 4 & 4 & 16 & 0,028030 & 4,176544 & 0,007462 \\
\hline $07.15-07.30$ & 5 & 9 & 45 & 0,052298 & 7,792479 & 0,1871170 \\
\hline $07.30-07.45$ & 6 & 15 & 90 & 0,081314 & 12,115823 & 0,686579 \\
\hline $07.45-08.00$ & 7 & 20 & 140 & 0,108367 & 16,146687 & 0,919570 \\
\hline $08.00-08.15$ & 8 & 20 & 160 & 0,126367 & 18,828771 & 0,072855 \\
\hline $08.15-08.30$ & 9 & 19 & 171 & 0,130985 & 19,516772 & 0,013683 \\
\hline $08.30-08.45$ & 10 & 13 & 130 & 0,122194 & 18,206922 & 1,489106 \\
\hline $08.45-09.00$ & 11 & 10 & 110 & 0,103630 & 15,440892 & 1,917201 \\
\hline $09.00-09.15$ & 12 & 9 & 108 & 0,080562 & 12,003825 & 0,751674 \\
\hline $09.15-09.30$ & 13 & 7 & 91 & 0,057812 & 8,613999 & 0,302414 \\
\hline $09.30-09.45$ & 14 & 7 & 98 & 0,038522 & 5,739913 & 0,276627 \\
\hline $09.45-10.00$ & 15 & 3 & 45 & 0,023958 & 3,569789 & 0,090946 \\
\hline $10.00-10.15$ & 16 & 3 & 48 & 0,013968 & 2,081379 & 0,405435 \\
\hline $10.15-10.30$ & 17 & 2 & 34 & 0,007665 & 1,142170 & 0,644275 \\
\hline $10.30-10.45$ & 18 & 2 & 36 & 0,003972 & 0,591952 & 3,349252 \\
\hline $10.45-11.00$ & 19 & 1 & 19 & 0,001950 & 0,290644 & 1,731276 \\
\hline $11.00-11.15$ & 20 & 1 & 20 & 0,000909 & 0,135568 & 5,511888 \\
\hline $11.15-11.30$ & 21 & 1 & 21 & 0,000404 & 0,060223 & 14,664903 \\
\hline $11.30-11.45$ & 22 & 0 & 0 & 0,000171 & 0,025537 & 0,025537 \\
\hline $11.45-12.00$ & 23 & 0 & 0 & 0,000069 & 0,010358 & 0,010358 \\
\hline & & 149 & 1390 & & & 33,531629 \\
\hline
\end{tabular}

Berdasarkan nilai batas kritis $\chi^{2}$ dengan taraf nyata $\alpha=0.05$ dan $k=24$, maka nilai $\chi_{(1-\alpha)(\mathrm{k}-1)}^{2}=\chi^{2}{ }_{(0.95)(23)}=35,172$. Sehingga diperoleh $\chi^{2}$ hitung $\leq \chi^{2}$ tabsl yakni $33,531629 \leq 35,172$ yang berarti jumlah keberangkatan bus berdistribusi Poisson. 


\subsubsection{Waktu Antar Kedatangan Bus}

\section{Uji Kesesuaian Eksponensial}

Untuk menghitung nilai $\chi^{2}$ dari data pengamatan pada $x_{1}, x_{2}$ sampai $x_{n}$ terlebih dahulu ditentukan nilai waktu pelayanan bus dengan menggunakan rumus distribusi eksponensial. Untuk menentukan nilai $\chi^{2}$ maka digunakan rumus

$$
\chi^{2}=\frac{(f(x)-E(x))^{2}}{E(x)}
$$

dengan $f(x)$ menyatakan frekuensi teramati dan $E(x)$ frekuensi harapan bagi sebaran ke- $i$. Kriteria keputusan dilakukan dengan terima rata-rata pelayanan berdistribusi eksponensial apabila nilai $\chi^{2}$ hitung $\leq \chi^{2}$ tabel, jika sebaliknya yaitu $\chi^{2}$ hitung $\geq \chi^{2}$ tabel maka rata-rata pelayanan tidak dapat dikatakan berdistribusi eksponensial.

\section{Tabel 4.4 Waktu Antar Kedatangan}

\begin{tabular}{|c|c|c|}
\hline $\begin{array}{c}\text { Lima } \\
\text { Belas } \\
\text { menit } \\
\text { ke- }\end{array}$ & $\begin{array}{c}f\left(x_{i}\right) \\
\text { keluar }\end{array}$ & $\begin{array}{c}\text { waktu } \\
\text { antar } \\
\text { kedatangan }\end{array}$ \\
\hline 1 & 0 & - \\
\hline 2 & 0 & - \\
\hline 3 & 1 & 15,00 \\
\hline 4 & 2 & 7,50 \\
\hline 5 & 4 & 3,75 \\
\hline 6 & 9 & 1,67 \\
\hline 7 & 15 & 1,00 \\
\hline 8 & 20 & 0,75 \\
\hline 9 & 20 & 0,75 \\
\hline 10 & 19 & 0,79 \\
\hline 11 & 13 & 1,15 \\
\hline 12 & 10 & 1,50 \\
\hline
\end{tabular}

\begin{tabular}{|c|c|c|}
\hline $\begin{array}{c}\text { Lima } \\
\text { belas } \\
\text { menit } \\
\text { ke- }\end{array}$ & $\begin{array}{c}f\left(x_{i}\right) \\
\text { keluar }\end{array}$ & $\begin{array}{c}\text { waktu } \\
\text { antar } \\
\text { kedatangan }\end{array}$ \\
\hline 13 & 9 & 1,67 \\
\hline 14 & 7 & 2,14 \\
\hline 15 & 7 & 2,14 \\
\hline 16 & 3 & 5,00 \\
\hline 17 & 3 & 5,00 \\
\hline 18 & 2 & 7,50 \\
\hline 19 & 2 & 7,50 \\
\hline 20 & 1 & 15,00 \\
\hline 21 & 1 & 15,00 \\
\hline 22 & 1 & 15,00 \\
\hline 23 & 0 & - \\
\hline 24 & 0 & - \\
\hline
\end{tabular}


Dari data diatas dapat ditentukan data minimum $\left(d_{\min }\right)$, data maksimum $\left(d_{\text {maks }}\right)$, rentangan data $(r)$, jumlah interval $(k)$ dan panjang interval $(\rho)$ sebagai berikut

$N=149$

$d_{\min }=0,75$

$d_{\text {maks }}=15,00$

$r=d_{\text {maks }}-d_{\min }=15,00-0,75=14,25$

$k=1+3,3 \log N=8,17 \approx 8$

$p=\frac{r}{k}=\frac{14,25}{8}=1,78 \approx 1,80$

Tabel 4.5 Interval Untuk Waktu Kedatangan Bus

\begin{tabular}{|c|c|c|c|c|}
\hline Interval & $x_{i}$ & $f\left(x_{i}\right)$ & $c_{i}$ & $f\left(x_{i}\right) c_{i}$ \\
\hline $0,75-2,55$ & 1,65 & 129 & 0 & 0 \\
\hline $2,56-4,36$ & 3,46 & 4 & 1 & 4 \\
\hline $4,37-6,17$ & 5,27 & 6 & 2 & 12 \\
\hline $6,18-7,98$ & 7,08 & 6 & 3 & 18 \\
\hline $7,99-9,79$ & 8,89 & 0 & 4 & 0 \\
\hline $9,80-11,60$ & 10,70 & 0 & 5 & 0 \\
\hline $11,61-13,41$ & 12,51 & 0 & 6 & 0 \\
\hline $13,42-15,22$ & 14,32 & 4 & 7 & 28 \\
\hline & & 149 & & 62 \\
\hline
\end{tabular}


$\bar{x}=x_{0}+p \frac{\sum f i . c i}{\sum f i}=1,65+1,8 \frac{62}{149}=2,39$

$\mu=\frac{1}{\bar{x}}=\frac{1}{2,39}=0,41$

$P(x)=\int_{x_{1}}^{x_{2}} \mu e^{-\mu x} d x$

dimana

$x_{2}=$ batas integral bagian atas

$x_{1}=$ batas integral bagian bawah

Tabel 4.6 Interval Untuk Perhitungan Nilai $\chi^{2}$ Waktu Antar Kedatangan Bus

\begin{tabular}{|c|c|c|c|c|c|}
\hline Interval & $\mathbf{x}_{\mathbf{i}}$ & $f\left(\mathbf{x}_{\mathbf{i}}\right)$ & $\boldsymbol{P}\left(\mathbf{x}_{\mathbf{i}}\right)$ & $\boldsymbol{E}\left(x_{i}\right)=\Sigma\left(f x_{i}\right) \boldsymbol{P}\left(x_{i}\right)$ & $\chi^{2}$ \\
\hline $0,75-2,55$ & 1,65 & 129 & 0,386083 & 57,52637 & 54,27369 \\
\hline $2,56-4,36$ & 3,46 & 4 & 0,181557 & 27,05198 & 20,57452 \\
\hline $4,37-6,17$ & 5,27 & 6 & 0,085378 & 12,72129 & 4,364474 \\
\hline $6,18-7,98$ & 7,08 & 6 & 0,040149 & 5,982233 & 0,201445 \\
\hline $7,99-9,79$ & 8,89 & 0 & 0,01888 & 2,813167 & 13,12681 \\
\hline $9,80-11,60$ & 10,70 & 0 & 0,008879 & 1,322902 & 66,4675 \\
\hline $11,61-13,41$ & 12,51 & 0 & 0,004175 & 0,622099 & 227,1698 \\
\hline $13,42-15,22$ & 14,32 & 4 & 0,001963 & 0,292544 & 672,614 \\
\hline & & 149 & & & 1058,792 \\
\hline
\end{tabular}

Berdasarkan nilai batas kritis $\chi^{2}$ dengan taraf nyata $\alpha=0.05$ dan $k=8$, maka nilai $\chi_{(1-a)(k-1)}^{2}=\chi_{(0.95)(7)}^{2}=14,067$. Sehingga dapat diperoleh $\chi^{2}$ hitung $\geq \chi_{\text {tabel yakni }}^{2}$ $1058,792 \geq 14,067$ yang berarti waktu antar keberangkatan bus tidak berdistribusi eksponensial. 
Model antrian untuk pola kedatangan bus adalah model (M/G/1) : (FIFO/ / ). Tingkat kedatangan berdistribusi Poisson. Waktu antar kedatangan bersifat umum dengan sebaran tertentu. Disiplin antrian yang digunakan adalah bus yang pertama datang yang pertama dilayani. Jumlah bus dalam sistem antrian dan ukuran populasi pada sumber masukan adalah tak berhingga.

\subsubsection{Pola Keberangkatan Bus}

\section{Uji Kesesuaian Poisson}

Untuk menghitung nilai $\chi^{2}$ dari data pengamatan pada $y_{1}, y_{2}$ sampai $y_{n}$ terlebih dahulu ditentukan nilai harapan keberangkatan bus dengan menggunakan rumus distribusi Poisson. Untuk menentukan nilai $\chi^{2}$ maka digunakan rumus

$$
\chi^{2}=\frac{(f(y)-E(y))^{2}}{E(y)}
$$

dengan $f(y)$ menyatakan frekuensi teramati dan $E(y)$ frekuensi harapan bagi sebaran ke- $i$. Kriteria keputusan dilakukan dengan terima rata-rata pelayanan berdistribusi Poisson apabila nilai $\chi^{2}$ hitung $\leq \chi^{2}$ tabel, jika sebaliknya yaitu $\chi^{2}{ }_{\text {hitung }} \geq \chi^{2}$ tabel maka rata-rata pelayanan tidak dapat dikatakan berdistribusi poisson. 
Tabel 4.7 Uji Data Keberangkatan Bus Dengan Distribusi Poisson

\begin{tabular}{|c|c|c|c|c|c|c|}
\hline $\begin{array}{c}\text { Lima belas } \\
\text { menit ke }\end{array}$ & $y_{i}$ & $\begin{array}{l}\text { Keluar } \\
\left(f\left(y_{i}\right)\right)\end{array}$ & $y_{i} f\left(y_{j}\right)$ & $P\left(y_{i}\right)$ & $E\left(y_{i}\right)$ & $\frac{[f(y i)-E(y i)] 2}{E(y i)}$ \\
\hline $06.00-06.15$ & 0 & 0 & 0 & 0,0000804 & 0,0111058 & 0,0111058 \\
\hline $06.15-06.30$ & 1 & 0 & 0 & 0,0007587 & 0,1047008 & 0,1047008 \\
\hline $06.30-06.45$ & 2 & 0 & 0 & 0,0035763 & 0,4935356 & 0,4935356 \\
\hline $06.45-07.00$ & 3 & 2 & 6 & 0,0112387 & 1,5509418 & 0,1300198 \\
\hline $07.00-07.15$ & 4 & 4 & 16 & 0,0264883 & 3,6553900 & 0,0324879 \\
\hline $07.15-07.30$ & 5 & 9 & 45 & 0,0499439 & 6,8922643 & 0,6445703 \\
\hline $07.30-07.45$ & 6 & 15 & 90 & 0,0784747 & 10,8295120 & 1,6060714 \\
\hline $07.45-08.00$ & 7 & 18 & 126 & 0,1056890 & 14,5850881 & 0,7995579 \\
\hline $08.00-08.15$ & 8 & 16 & 128 & 0,1245484 & 17,1876808 & 0,0820695 \\
\hline $08.15-08.30$ & 9 & 18 & 162 & 0,1304649 & 18,0041648 & 0,0000009 \\
\hline $08.30-08.45$ & 10 & 11 & 110 & 0,1229963 & 16,9734916 & 2,1022547 \\
\hline $08.45-09.00$ & 11 & 10 & 110 & 0,1054138 & 14,5471097 & 1,4213275 \\
\hline $09.00-09.15$ & 12 & 8 & 96 & 0,0828160 & 11,4286170 & 1,0285946 \\
\hline $09.15-09.30$ & 13 & 7 & 91 & 0,0600578 & 8,2879770 & 0,2001555 \\
\hline $09.30-09.45$ & 14 & 7 & 98 & 0,0404426 & 5,5810859 & 0,3607392 \\
\hline $09.45-10.00$ & 15 & 3 & 45 & 0,0254183 & 3,5077260 & 0,0734908 \\
\hline $10.00-10.15$ & 16 & 3 & 48 & 0,0149769 & 2,0668258 & 0,4213291 \\
\hline $10.15-10.30$ & 17 & 2 & 34 & 0,0083056 & 1,1461809 & 0,6360313 \\
\hline $10.30-10.45$ & 18 & 2 & 36 & 0,0043501 & 0,6003145 & 3,2634878 \\
\hline $10.45-11.00$ & 19 & 1 & 19 & 0,0021584 & 0,2978677 & 1,6550622 \\
\hline $11.00-11.15$ & 20 & 1 & 20 & 0,0010174 & 0,1404079 & 5,2625116 \\
\hline $11.15-11.30$ & 21 & 1 & 21 & 0,0004567 & 0,0630333 & 13,9276424 \\
\hline $11.30-11.45$ & 22 & 0 & 0 & 0,0001957 & 0,0270113 & 0,0270113 \\
\hline $11.45-12.00$ & 23 & 0 & 0 & 0,0000802 & 0,0110717 & 0,0110717 \\
\hline & & 138 & 1301 & & & 34,2948309 \\
\hline
\end{tabular}

Berdasarkan nilai batas kritis $\chi^{2}$ dengan taraf nyata $\alpha=0.05$ dan $k=24$, maka nilai $\chi_{(1-\alpha)(\mathrm{k}-1)}^{2}=\chi^{2}{ }_{(0.95)(23)}=35,172$. Sehingga diperoleh $\chi^{2}$ hitung $\leq \chi^{2}$ tabel yakui $34,2948309 \leq 35,172$ yang berarti jumlah keberangkatan bus berdistribusi Poisson. 


\subsubsection{Waktu Antar Keberangkatan Bus}

\section{Uji Kesesuaian Eksponensial}

Untuk menghitung nilai $\chi^{2}$ dari data pengamatan pada $y_{1}, y_{2}$ sampai $y_{n}$ terlebih dahulu ditentukan nilai waktu pelayanan bus dengan menggunakan rumus distribusi eksponensial. Untuk menentukan nilai $\chi^{2}$ maka digunakan rumus

$$
\chi^{2}=\frac{(f(y)-E(y))^{2}}{E(y)}
$$

dengan $f(y)$ menyatakan frekuensi teramati dan $E(y)$ frekuensi harapan bagi sebaran ke-i. Kriteria keputusan dilakukan dengan terima rata-rata pelayanan berdistribusi eksponensial apabila nilai $\chi^{2}$ hitung $\leq \chi^{2}$ tabel, jika sebaliknya yaitu $\chi^{2}$ hitung $\geq \chi_{\text {tabel }}^{2}$ maka rata-rata pelayanan tidak dapat dikatakan berdistribusi eksponensial.

\section{Tabel 4.8 Waktu Antar Keberangkatan}

\begin{tabular}{|c|c|c|}
\hline $\begin{array}{l}\text { lima belas } \\
\text { menit ke- }\end{array}$ & $f\left(y_{i}\right)$ & $\begin{array}{l}\text { waktu antar } \\
\text { keberangkatan }\end{array}$ \\
\hline 1 & 0 & - \\
\hline 2 & 0 & - \\
\hline 3 & 0 & - \\
\hline 4 & 2 & 7,50 \\
\hline 5 & 4 & 3,75 \\
\hline 6 & 9 & 1,67 \\
\hline 7 & 15 & 1,00 \\
\hline 8 & 18 & 0,83 \\
\hline 9 & 16 & 0,94 \\
\hline 10 & 18 & 0,83 \\
\hline 11 & 11 & 1,36 \\
\hline 12 & 10 & 1,50 \\
\hline
\end{tabular}

\begin{tabular}{|c|c|c|}
\hline $\begin{array}{l}\text { lima belas } \\
\text { menit ke- }\end{array}$ & $f\left(y_{i}\right)$ & $\begin{array}{l}\text { waktu antar } \\
\text { keberangkatan }\end{array}$ \\
\hline 13 & 8 & 1,88 \\
\hline 14 & 7 & 2,14 \\
\hline 15 & 7 & 2,14 \\
\hline 16 & 3 & 5,00 \\
\hline 17 & 3 & 5,00 \\
\hline 18 & 2 & 7,50 \\
\hline 19 & 2 & 7,50 \\
\hline 20 & 1 & 15,00 \\
\hline 21 & 1 & 15,00 \\
\hline 22 & 1 & 15,00 \\
\hline 23 & 0 & - \\
\hline 24 & 0 & - \\
\hline
\end{tabular}


Dari data diatas dapat ditentukan data minimum $\left(d_{\min }\right)$, data maksimum $\left(d_{\text {maks }}\right)$, rentangan data $(r)$, jumlah interval $(k)$ dan panjang interval $(p)$ sebagai berikut

$$
\begin{aligned}
& d_{\text {min }}=0,83 \\
& d_{\text {maks }}=15,00 \\
& r=d_{\text {maks }}-d_{\text {min }}=15,00-0,83=14,17 \\
& k=1+3,3 \log N=8,06 \approx 8 \\
& p=\frac{r}{k}=\frac{14,17}{8}=1,77 \approx 1,80
\end{aligned}
$$

Tabel 4.9 Interval Untuk Waktu Keberangkatan Bus

\begin{tabular}{|c|c|c|c|c|}
\hline Interval & $\boldsymbol{y}_{\boldsymbol{i}}$ & $\boldsymbol{f}\left(\boldsymbol{y}_{\boldsymbol{i}}\right)$ & $\boldsymbol{c}_{\boldsymbol{i}}$ & $\boldsymbol{f}\left(\boldsymbol{y}_{\boldsymbol{i}}\right) \boldsymbol{c}_{\boldsymbol{i}}$ \\
\hline $0,83-2,63$ & 1,73 & 119 & 0 & 0 \\
\hline $2,64-4,44$ & 3,54 & 4 & 1 & 4 \\
\hline $4,45-6,25$ & 5,35 & 6 & 2 & 12 \\
\hline $6,26-8,06$ & 7,16 & 6 & 3 & 18 \\
\hline $8,07-9,87$ & 8,97 & 0 & 4 & 0 \\
\hline $9,88-11,68$ & 10,78 & 0 & 5 & 0 \\
\hline $11,67-13,49$ & 12,58 & 0 & 6 & 0 \\
\hline $13,5-15,3$ & 14,4 & 3 & 7 & 21 \\
\hline & & 138 & & 56 \\
\hline
\end{tabular}

$$
\begin{aligned}
& \bar{y}=y_{0}+p \frac{\sum f i . c i}{\sum f i}=1,73+1,8 \frac{56}{138}=2,46 \\
& \mu=\frac{1}{\bar{y}}=\frac{1}{2,46}=0,40 \\
& P(y)=\int_{y_{1}}^{y_{2}} \mu e^{-\mu y} d y
\end{aligned}
$$


dimana

$y_{2}=$ batas integral bagian atas

$y_{1}=$ batas integral bagian bawah

Tabel 4.10 Interval Perhitungan Nilai $\chi^{2}$ hitung Waktu Antar Keberangkatan Bus

\begin{tabular}{|c|c|c|c|c|c|}
\hline Interval & $y_{i}$ & $f\left(y_{i}\right)$ & $P\left(y_{i}\right)$ & $E(y i)=\sum f(y i) P\left(y_{i}\right)$ & $\chi^{2}$ \\
\hline $0,83-2,63$ & 1,73 & 119 & 0,370287 & 51,09957 & 47,69814 \\
\hline $2,64-4,44$ & 3,54 & 4 & 0,177441 & 24,48679 & 17,91856 \\
\hline $4,45-6,25$ & 5,35 & 6 & 0,085029 & 11,73401 & 3,473287 \\
\hline $6,26-8,06$ & 7,16 & 6 & 0,040746 & 5,622909 & 0,420183 \\
\hline $8,07-9,87$ & 8,97 & 0 & 0,019525 & 2,694484 & 14,61582 \\
\hline $9,88-11,68$ & 10,78 & 0 & 0,009356 & 1,29119 & 69,73218 \\
\hline $11,67-13,49$ & 12,58 & 0 & 0,004554 & 0,628468 & 227,2814 \\
\hline $13,5-15,3$ & 14,4 & 3 & 0,002149 & 0,296496 & 670,8642 \\
\hline & & 138 & & & 1052,004 \\
\hline
\end{tabular}

Berdasarkan nilai batas kritis $\chi^{2}$ dengan taraf nyata $\alpha=0.05$ dan $k=8$, maka nilai $\chi_{(1-\alpha)(\mathrm{k}-1)}^{2}=\chi_{(0.95)(7)}^{2}=14,067$. Sehingga dapat diperoleh $\chi^{2}$ hitung $\geq$ $\chi^{2}$ tabel yakni $1052,004 \geq 14,067$ yang berarti waktu antar keberangkatan bus tidak berdistribusi eksponensial.

Model antrian yang diperoleh adalah model $(\mathrm{M} / \mathrm{G} / 1)$ : (FIFO/ / ). Tingkat keberangkatan berdistribusi Poisson. Waktu antar keberangkatan bersifat umum. Disiplin antrian yang digunakan adalah bus yang pertama datang yang pertama 
dilayani. Jumlah bus dalam sistem antrian dan ukuran populasi pada sumber masukan adalah tak berhingga. 


\section{BAB V}

\section{PENUTUP}

\subsection{Kesimpulan}

Berdasarkan hasil pembahasan yang telah disajikan di atas, maka dapat disimpulkan bahwa

1. Model antrian data kedatangan bus dan data keberangkatan bus yang diperoleh adalah model $(\mathrm{M} / \mathrm{G} / 1)$ : (FIFO/ / ) . Tingkat kedatangan dan tingkat keberangkatan berdistribusi Poisson. Waktu antar kedatangan dan waktu antar bersifat umum. Disiplin antrian yang digunakan adalah bus yang pertama datang adalah bus yang pertama dilayani. Jumlah bus dalam sistem antrian dan ukuran populasi pada sumber masukan adalah tak berhingga.

2. Dari analisis data pada waktu kedatangan bus, diperoleh nilai kedatangan ratarata $(\lambda)=0,41$ bus per menit, ekspektasi kecepatan pelayanan rata-rata $(\mu)=$ 0,107 bus per menit. Dari analisis data pada waktu keberangkatan bus, diperoleh nilai keberangkatan rata-rata $(\lambda)=0,383$ bus per menit, ekspektasi pelayanan keberangkatan rata-rata $(\mu)=0,106$ bus per menit .Hal ini bawasanya bus yang sudah datang memasuki halte, yang seharusnya berangkat tetapi masih berada di halte sehingga menyebabkan adanya antrian bus. 


\subsection{Saran}

Bagi unit pengoperasian bus kampus agar memperhatikan tingkat kedatangan bus dan tingkat keberangkatan bus untuk selalu di analisa dalam suatu priode waktu, perlu adanya perbaikan kinerja dari proses pengoperasian yang mempunyai sifat ketidakpastian tersebut. Dengan demikian dapat optimal dalam melayani mahasiswa menuju ke kampus, sehingga tidak ada bus yang terlalu lama berada di dalam halte. 


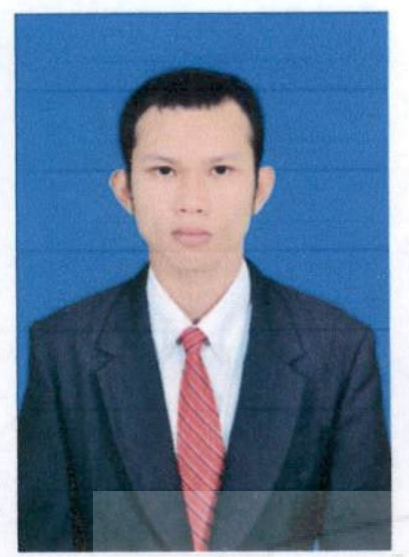

Penulis bernama Zul Ahmad Ersyad, dilahirkan di Tampunik pada tanggal 05 Agustus 1988 dari pasangan Syarifuddin dan Ernadiatni. Penulis adalah anak ke 2 dari empat bersaudara. Penulis menamatkan pendidikan sekolah dasar di SD N 48 Daratan Merantih pada tahun 2000, SMP N 3 Lengayang pada tahun 2003, dan SMA N 1 Lengayang pada tahun 2006. Pada tahun 2006, penulis diterima sebagai mahasiswa jurusan matematika Fakultas Matematika dan Ilmu Pengetahuan Alam universitas Andalas Padang melalui jalur SNMPTN (Seleksi Nasional Masuk Perguruan Tinggi Nasional).

Selama masa perkuliahan, penulis aktif dalam berbagai organisasi. Penulis aktif sebagai Anggota Divisi Seni Kelompok Kegiatan Seni (KKS) MIPA Unand periode 2009-2011. Selain itu, penulis pernah aktif sebagai anggota Himpunan Mahasiswa Matematika (HIMATIKA) Unand, Penulis melaksanakan Kuliah Kerja Nyata (KKN) pada tahun 2008 di Nagari Tarantang, kecamatan Harau, Kabupaten Lima Puluh Kota dalam rangka menyelesaikan salah satu mata kuliah wajib fakultas. 